\title{
Ervehe as Moral Triumph and Trial of the Woman Who Explores the Social Utopia
}

\author{
RAHIM OMBASHI* \\ University "Hëna e Plotë - BEDËR" Tirana ALBANIA \\ *Corresponding author: r-ombashi@hotmail.com
}

Received June 16, 2014; Revised June 26, 2014; Accepted July 01, 2014

\begin{abstract}
The masterpiece of Muhammad Kyçyku alamiado writer (1784-1844) Erveheja became the most recognized in the period of the Albanian National Renaissance literature, after its first publication, in 1888, in Bucharest, by Jani Vreto. While the number of those who could read the Arabic alphabet was very low, the narrative poem, with only 214 stanzas of four verses, and with octosyllable range, was enjoyed and understood in listening by many admirers. The cause of the massive proliferation should be seen in the simplification of the poetic creation after two adaptations, but also of the social mission of this kind of utopian literature. Being a deliberate literature, it more strongly influenced the listener in the socio-cultural context, as the determining one of the text. After the discovery and the publication of the original text, Erveheja realized a kind of criticism, since the nucleus to understand reading a work of art is hidden within it. More importance was given to the text, by passing the universal themes, as the field of literature which gives the content, but also to the cultural themes, relating to Islam and Islamic culture. The idea that emerges as a dominant feature of the work is individual and the related topics are the pain of life and some other sub topics relating to it. Therefore, the collections of the information will pass on reflective analysis, which will help in accessing the social reality of the dream.
\end{abstract}

Keywords: social utopia, customized, mission, reflective analysis, social reality

Cite This Article: RAHIM OMBASHI, "Ervehe as Moral Triumph and Trial of the Woman Who Explores the Social Utopia." American Journal of Educational Research, vol. 2, no. 7 (2014): 480-485. doi: 10.12691/education-2-7-9.

\section{Introduction}

Muhammad Kyçyky (1784-1844) was recognized in the literature with the name Muhammad Chami, a Mehmet name, after his work, Erveheja, was published posthumously in 1888 in Bucharest by Jani Vreto, who transcribed and combed it of foreign words. At the top of the first edition, which was reprinted in 1910 with the alphabet of the Istanbul Society, it is noted that the work was suppressed with the help of patriots. At that time Romania had a large Albanian community that dealt not only with the economic activity, but also with cultural and patriotic activities. The Bucharest expatriate community had reached its newspaper and printing office, where many books were printed with the alphabet of the Istanbul Society. At the introduction of the publication, Jani Vreto explains that the poem was given to Resul Efendi of Gjirokaster. The poem, handwritten by Haydar Gjirokastriti, was read to him by Avni Efendi, who knew Arabic alphabet letters. At the end, the poem was published by Haydar Gjirokastriti, who says:

Muhammad finished three parts,

A part of the poverty Haydar.[1]

[Erveheja. Translated by R. Ombashi]

Below this, Jani Vreto adds that Haydar Gjirokastriti "filled" Muhammad Kyçyku’s poem with an additional part. In the Introduction, the publisher states that he had knowledge of Muhammad Kyçuku's original work, which was in Chameri, but was unable to find the one who had it "to lift and to see how and where changes" (Chami M., 1910). From this assertion from the publishers, we learn that he had first raised interest in the work of Muhammad Kyçyku for its moral values, teaching and education, but did not insist on finding the original, although he notes that the creation of customized has a beautiful fort. Notwithstanding the fact that this renaissance activist has knowledge of several languages and a good philosophical training for the period, he fails to separate the definition of literature as a value in itself, but as artistic consciousness he knows how to distinguish good moral and educative values. At this level of theoretical literature would have been Haydar Gjirokastriti, who would go on to become a member in the poem of Muhammad Kyçuku. It is the time when in the Ottoman Empire, Albanians were referred to by the name of the region they were from:

"This poem of the suffering of Erveheja was given to us from Resul Argjirokastriti written in Arabic letters from Haydar from Argjirokastra, who was a poet and elder, and was sang everywhere from Avni to Argjirokastra. ..".

At the end of the poem, the name of additional people, its copier Hodo Kastriti (so is said more in Albanian to Haydar, explains Jani Vreto), and Hodo Kastra were given. It seems that at the end of the nineteenth century national identity was more important than individual identity, and 
thus Muhammad Kyçuku was introduced into the literature with the literary name Chami, which was the name of his province. That Jani Vreto aimed to achieve more in the field of education by entertaining, is supplemented even below, when Jani Vreto responds to Hodo Gjirokastriti who, in addition to his verses, requires from Erveheja to be only for readers of the same belief as the author: ". .., I am their true brother and the blood ever becomes water "(Chami M., 1910). In 1910 the poem was reprinted in Thessaloniki, in Prosperity, and in the 1920s, the poem was reprinted from Dhori Kotti with the Alphabet of Monastery. After the Second World War, a time proceeding scientific expedition in the suburbs of Konispol, the original work and other writings of the author were founded. (Universiteti Shtetëror i Tiranës, 59) The original poem was first published in Bulletin Social Sciences, Tirana, 1957 / 2 transcript of the Osman Myderrizi. From a quick approach, it appears that the text of Jani Vreto was of a lower artistic level than the original, but his educative role was enormous:

The text of M. Kyçyku

Right now is the time,

to remember God;

the poor, I ran out of patience,

that will melt as candle.

The text of Jani Vreto

Today arrived my day,

If you remember God;

Among your feet I was spread out,

If you want kick me and take my soul.

[Erveheja. Translated by R. Ombashi]

In the introduction of its publication, Jani Vreto provides no other information about the author, whom we already know and other facts that might help to interpret the work. Muhammad Kyçyku was born in Konispol, in the region of Chameri, where he attended a religious school. He went on to pursue religious studies in Cairo, Egypt, where he stayed for 11 years. Prior to this period he had lived as an imam. He began by adapting literary works from oriental languages, which he knew well, but he also wrote real literature. He also wrote other works, but it was narrative poems such as Erveheja that gave him the glory he deserved because of the help they provided in different areas of the social life. The poem was written in about 1820, when the Ottoman Empire and the Islamic world were exposed to a very terrible crisis. Muhammad Kyçyku apparently tried to find the most important diagnosis to cure the crisis. Some of his views threw light on a better present, in function of the future. According to him, the crisis may have been stronger in societies that lacked spirituality, which is one of the most important sources of power in society. He was born in a Muslim community where he grew up, and after completing his education, worked as an imam. He was very close to the Sunni faith. Although he felt a strong relationship with state power, he believed that spiritual formation and spiritual identity was the base upon which to cope, as well as weaken, the crisis of the entire empire. Otherwise, he argued, it could cause serious problems in the Albanian society, where social wounds deepen. Literature, he thought, was created to build a better world where people live, for it creates the image of women lapidary; the more fragile and the more attacked of those who wore the ugly features were reinforced by the crisis. Spirituality is one of the most important sources of power for societies and this is the basis in which Muslim communities believe in God. Otherwise, serious problems may be caused in the society. This unfavorable situation can be reflected in the field of ethics. Thus he says in a poem:

Moral elevation, not information and not conscience,

Sense of virtue, but the fear of God in the people. (Faruk Kiliç A., 2013).

Poets having the chance to feel that society interacts phenomenon then directed artistic time, which does wearer, that's for Muhammad Kyçyku laid the foundation of his poem in verses of religious ethical problems, which serves as a document for other fields of knowledge.

\section{The Social Utopia of Narrative Poem Erveheja}

The poem was spread among readers and listeners to approach the original text. For the Albanian society of that time, it was a common occurrence, which will continue for too long. Thus, it served on many devices, especially as a model for a society in crisis. Being a point of verses, it was learned by heart, recited in Albanian areas, where there were a few who were able to read the Ottoman alphabet. A number of Sufi Islamic movements, which were created in the Middle East by XI-XII onwards, quickly crossed the Bosphorus. (Karamustafa T. A.,1994), The relations to Islamic culture were placed from the thirteenth century with Sari Saltuk, who along with his supporters, represents the first Muslim community in the Balkans. (H. Musa Taşdelen, 2013) If Sufism in the previous century had found the need to spreading it in some prosperous cities of the time, even in the countryside, then official Sunnism became dominant. The religion of the common substrate in the form of a religious character and highly syncretism nature of Bektashi religious line as completely unofficial, as noted from the ethnologist Albert Doja, (Doja A., 2006) in this period had left the place to the official line. When the individual cannot cope with the crisis, he had to face the cell itself and the holy family. There are a growing number of those leaving the military in economic exile, while the family was left to the woman as the door to the world. The patriarchal family of the time tried to tighten ranks, when the wife lacked husband control under its power. She was not only left with the mother in law, but a brother in law was also usually left at home. The laws of survival were a rising habit that damaged the family. Within the patriarchal family, moral incest appeared in many cases. For the family, there had been a continuous effort to fight for, and to defend, monogamy, by entering into legal codes, and the codes of faith, as a moral institution. Poverty and the lack of an economic model had created an institution of ingratitude. The economic dependence, lack of protection from the law, and social norms lead Albanian women to the limits of an accepted slavery. To Muhammad Kyçyku, the underlying figure of women conveys the message of the Prophet Muhammad, that every man should measure himself in relation to the correctness of his relationship with his wife (his family), The poem is perhaps victorious in portraying this struggle. Erveheja will remain under the care of the husband's brother, without shaking his cradle, protected from street violence, which saw women only as 
a means of entertainment. Frustrations of people will have the range, but they never lost faith in God, with which they have stable relations:

\section{The money I paid}

At checkout the kingdom,

To you, my soul to do regards,

But for God's sake.

[Erveheja. Translated by R. Ombashi]

The family gave signs of disintegration, while individuals aiming to preserve life at all costs, and was undermining its values. The fable set the Erveheha in special conditions. Gender of her husband's small, near the couple's house is located only a bachelor's husband's brother. The poem found support by spreading the hadith of the Prophet, which makes mothers three times more important than the father because they take the life pattern of departure. In the Islamic family, marriages are based on sacrifice, loyalty and obedience. The author has made sure that all councils embody the protagonist of the poem, who contrasts with the individual and violent environment of the time. The insulted, unfairly damaged, never finds time to analyze characters or reach people who intend to harm because there is no place for women who could have the habit of asking the way to errors, to blame and criticize. Speak with little more patience and silence speaks, adds itself to the features that add to the beauty, of which finds misfortune occurred. From the first verse with which the author begins her portrayal of the interest to know him, it explores the actions conducted themselves, adding value to yourself. After describing the early poems, it immediately enters its role, and begins to display character traits that breed violence. It immediately begins to respect and then soon love her character, what it lacks sees society in which she lived, but you cannot ever forget. When the marriage kindergarten breaks, Erveheja knows how to maintain spiritual tranquility by pretending to reach it in its rebuilding. This purity makes her enjoy the benefits of the other protagonists, taking the mission of woman who enjoys healing people regardless of vices and blindness. Half a century later, Mother Teresa thus wants to order the same thing: "What can you do to promote peace in the whole world? Go home and love your family".

\section{Sociopolitical Context, Cultural and Historic Mission of the Social Work}

"This short poem precedes to romantic narrative poems. In his masterpiece Erveheja, Muhammad Kyçyku creates a complete poem, where man in his triumph moral character is tested and Erveheja is the first literary character in Albanian literature" (Hamiti S., 2010).

The heroin trials attested to the social situation in which Albanian society existed. The crisis of the powerful Ottoman Empire had encouraged the Balkan peoples, aiming to create their states after secession from the empire. Echoes of the French Revolution added intellectuals' empire efforts to monitor, and take care of, the Turkish language enrichment as a precondition for the creation of a national state in the future. This was the interest of intellectuals of all nations that formed the empire. An Erveheja poem of Muhammad Kyçyku's brought further safety to Albanian creators, because it was to serve as a basis for subsequent creations. Although conceived over a Turkish narrative, it was processed as an authentic text, where the case was entirely Albanian. In addition to the problems that had caused the crisis throughout the Empire, she discovered that the problem was entirely of Albanian nature. By creating the myth of the woman, she left mythical models. The above evaluation of the researcher Sabri Hamiti about the role of the poem in the history of Albanian literature shows both strong artistic ferment that gave a conflicting and murky reality of the time. Monumental figures of Albanian women, watched to micromanage spiritual society of the time served, but left idle things like deeds, which made creators to be filled with artistic creation. By accumulation between stylistic figures of admonition and sarcasm, the poems removed praise for her verses the divan, with which our literature began with the Arabic alphabet, as evidence of an individual idealized art and identification becomes the creator. By creating an ideal image as a model of moral ethics, work makes penetration of social utopia actually served as historical time. After construction philosophy, the poem is ideological discourse, because we can discover its possible link with a certain reality or sociological and political factors that have to be determined (Doja A., 2008). In this way it serves as a social document of the time, which comes to our time, because the poem has value as a social product such as a communication tool between historic times. It will serve as a model for subsequent creators, who will help Albania. The moral narrative poem of 856 verses, divided into fourverse, is written around the year 1820 . The author took the fable of a story in prose in Turkish Revza (Park), which creates the original moral poem. The language of the poem, both the composition, and the details of the findings, give the poem status of authenticity. The fables of Erveheja poems wander about events, vicissitudes of an Albanian woman, who knows the extreme sacrifice to remain how she was in the time when her husband left. She suffers, wanders into the world of troubles, goes on the verge of death several times, but does not submit at any moment to loss of faith in God. Her personal spiritual integrity helps her to pass the pitfalls that arise everywhere, and to be rewarded for moral fortitude. She is saved by the intervention of God at the end by getting her reward of virtue, family recreation, and even sex, expanded. The author has noted that Erveheja was written to the respondent, the greater amount of people. After a short exposure, the author begins the story, which has no room for thought. Fables and character help to give a broader view of all the people. Epic in Medias res (Latin "in the midst of things") the author's technique introduces us to the development of action without trying to finalize it soon. The first part of the poem has dramatic tension, while the second, as the ending sacrifices, no more repetition, thus the author's concern to pass the message. The beautiful Erveheja, smart, happy in marriage, yet will remain alone in her house because her husband "fell leaving for work". By not revealing any specific reason for leaving the family, the poem lacks of specificity and feeling as well as the fact that the author intended to convey a moral massage. The fables discuss leaving to the single brother as a testament of the wife. It gives his covenant that he will take care of his sister in law. Erveheja, who was very beautiful, begins to suffer. Notwithstanding this, the brother in law wants to go to bed 
with her, although he gave his commitment. He faces resistance by accusing her of being unfair. Hence, he buys witnesses so as to punish her, by executing her with stones. Left in the situation of half-dead under the cairn, when passing nearby a generous (arap), Jani Vreto, the publisher, writes that the original was arap (in Albanian means black man), but he replaced the word generous (noble), which tells us that the replacement is in line with the silent Turkish consonant (b), (p) in the word Arapça (Arabic). Arabic, comes from the name arap meaning one who speaks Arabic and not black. The most positive character of the poem, who saves the poem's heroine's life, having terrible consequences, the author of labels with the name of a resident of that people choose who brought the man, who hosted the Holy Qur'an, he had to support the nobility the Messenger of God. Arabian man, who hears the groans of Erveheja, dying under the newly established stacked stones was arap (generous, noble), but not arap (black man). Being convinced that the homonym will affect the delivery of the message, Jani Vreto replaced the word by adding a dose of adjustment. This positive character is a member of another population; therefore the poem proves the acceptance of cultural diversity as richness for the Ottoman Empire. Intrigue of the poem with strong dramatic elements, started from the brother in law, who does not know if he is distracted by the temptation of special beauty Erveheja, or blinded by unfaithfulness. However, Erveheja will face problems because of her rare beauty, even in other episodes of the poem. Based on Faik Konica thought: "Just found out that I had actually achieved in Albania, a country blessed with a thousand kind of rare beauties, is violated by a crowd, which breeds hatred against a certain beauty" [9] must recognize that this hatred should have been stronger a century ago, especially in times of crisis. The author did not identify the noble, because of the need to create the myth of individualization of the heroin. He leads her to his own house, the person found under the cairn, and serves her together with his wife. The problem again is the rare beauty. As she was healed, she becomes so beautiful. The noble offers her marriage, according to the Qur'an code on marriage with a woman for charity. She knows the Holy Qur'an, the provisions of Islamic Sharia; he knew they were necessary to implement the provisions of Orient spiritual life, physical and interpersonal relationships, and family rules, in marriage. Despite everything, she survives this difficult stage by convincing the man, a believer, of the kindness he had shown by saving lives, and that he should not derail. If he actually considers marrying her as an orphan, similarly she manages to convince him that she has another status. He had to deal further with the temptation that caused the noble servant, who for revenge, since she refused to marry him, killed the son of the noble, but indicted Erveheja for the crime. The war became an obligation, though she hated it. She was given wisdom and goodness as well as great grace. Nevertheless, she is on the verge of a catastrophe, because she has to go on the road, after proving that she is innocent. Honoring the loyalty of Erveheja, a nobleman gives the gift of the crown, niqah, as she was a member of the family, but she had to leave that unfortunate home. At the edge of a road, with niqah separated from the nobles, she saves the lives of men who owed money to this noble. Again there is a proposal of marriage, to escape from death and violence, in order to realize again the masculine desires. After rejecting her, the nobleman sells her as a slave to a ship's Captain, but the disasters do not come to an end. Even as a slave she fails to be protected from the honor and the dignity as a person. Finally, thanks to the aid of divine intervention, the ship sinks and, with its people mired in vice, God casts Erveheja alive onto the sea shore. After the first part of poems, with so many social meeting points with the absurd reality of the Albanian society of the early nineteenth century, the plot of the second part of the poem continues to wander into a world of wonders, as divine reward for the loyalty of the heroine. She dresses like a man and manages to get permission from the king to stay in the place where the tide turned, treating blindness (disease of ignorance), and gaining fame and reputation all around the place. When the seat remains empty because of no heir, the royal council decided at the top of the kingdom, becoming one with the opinion of the king, who infuses relieved after that wise judgment. Continues to serve as healers and notoriety achieved its town, where unduly suffer. Come to cure her brother in law, coupled with brother, the servant with the noble who appear contrite. When finally heals she shows who she really was. Lay the throne of her husband asks the noble to bring his wife, to have her as a mother, forgives the brother in law and the servant. The metrical story has dramatic tension, until she manages to get the right to stay in the place where she was thrown after the sea storm. Everything in the poem wanders around the figure of Erveheja, which serves to develop narrative fables.

Erveheja was a woman,

At that day she had no friends,

Girl and married,

Like the moon gives light when.

Beauty had to sign,

Strongly that a fair lady,

Husband had made remarkable

And fine features.

[Erveheja. Translated by R. Ombashi]

The word woman means lady, according to the tradition of the time, but even in Islam. Thus, the attendance of female education is seen in childhood and later. However, there is a reflection of light from the moon. The beauty as portrayed proved that Albanians have a problem with beauty, but not with nobility:

"So, if in Albania beauty is despised and kicked, surely nobility, one of the virtues of the nation's oldest, Albanian, is alive and gets a new power from the example of Him who should life and the blessings mirrors the spirit and behavior. .."

The values of Erveheja come to complement a moral man, which shows a step in relation to time in this regard. Lead author of the earlier opinion of her, because she has a role in strengthening the positive traits of his spouse, not simply left in the reflection of the light of men: "Like the moon gives light when". Positive features embodied by their actions during the elaboration of the work, create the background of hope for society in the future. Erveheja is an example of goodness and devotion to the people. To save a stranger gives all her niqah. Although she has a strong character, she managed to be subjected to Albanian sanguine temperament. In not known to take revenge, because it accepts the component "vindictive", "of Albanian identity, a component of this, which did not 
feature as the main European cultural identity" (Frashëri K., 2006), as an Islam faith that nurtures spiritual goodness and peace. Heroin invite Albanian resident of any time, of both sexes and all social strata, especially the Albanians in times of crisis, to prevent falling into a spiritual crisis, which depends entirely on the individual. Consolidating spiritual identity, can afford to reach, as well as reduce, the impact of the crisis on the whole of society in general. Therefore, Erveheja's figure is as the first in Albanian literature to be skewed by social perfection, with the aims of rising to the level of a spiritual being, approaching the divine. The story is running full of joy of life and dramatis. Thus, dialogue is close to conversational discourse, full of color, while the octosyllable verse enables the author to individualize characters through language or actions performed.

\section{Discussion}

Muhammad Kyçuku chose the myth of woman as a place where he committed his social meditation. The Albanian mythical beings have several feminine figure, entering deep into history. With Erveheja figure created the first female character, but at the same time begins the myth of women in our literature individualized that in Renaissance literature will be the primary. The rummage social situation of where she lives, as she is under the care and protection of her husband, enable the author to find the specific, without glaze, social, economic, spiritual, moral, ethical, religious etc. for which needed the Albanian society of the time, some of which appear now. The woman is as a natural being, but also with social and spiritual, outdoor living, family and community. Thus, numerous problems which occurred around Erveheja are at that time of problems, even more powerful than an historical time. Under the artist we find facts of their plan not to leave the family organization, social, customary law of our people in the last century of the existence of the Ottoman Empire, when signs of creating separate states are looked at. As the researcher Adem Balaban says in his own work: The importance of Using Language in crisis Management: "Whether before or after such during crisis, the proper and correct use of language by political leaders, media and people, may prevent and reduce conflicts" (Balaban A., 2013). The narrative poem Erveheja written in Albanian, though with Arabic alphabet, shows that language does not only prevent conflicts but also manages to convince the moral educate, as well as in the Islamic faith. Erveheja uses this communication tool to inform, advise, persuade and argue with, the other characters of the narrative poem. The word said by the positive characters in the poem strength gains, brings problem solving gives pleasure, quite different from the words of the negative characters. Being a woman, she does not know how to separate the people who need help. Hence, the generous brings home the woman found under cairn, without knowing her religious faith, her social layer or her ethnic origin. Erveheja saves the needy from death, which has damaged the ark of the ruler, gives 400 gold coins because it accounts do not know when it would be appropriate goodness, without knowing his faith. In addition, it also stated the generosity of the king who gives shelter, and cures the blind without knowing their belief or religion. For this reason the poetic work Erveheja became dear to all Albanian citizens, regardless of religion.

\section{Conclusions}

If with the divan of Nezim Frakulla the Albanian literature indicates that they got the creative and stimulating model of the Islamic literature to enter the path of creating individual poetry. With the narrative poem by Muhammad Kyçyku Erveheja, the literature laid the foundations of narrative poem, which would quickly encourage other genres expected to emerge, while maintaining the artistic sensibility helps the native language to fill the spiritual elements of personal identity. Being artistic documents in time, many hardened details which were explained contribute to historical time and simultaneously serve as reference points for communicating across generations. The elements of Islamic poetry: God, faith, moon, temporality of earthly life full of all the deprivations facing the divine dignity, to live spiritually and to sacrifice etc. These elements are parallel to the Albanian mythical poetry, clocks, craft, sylph, the foundations of the myth of Magna Mater, like an echo of an Anatolian goddess cult, which makes the image of Erveheja more than Albanian, more than about a particular environment (Roller, Lynn E., 1999). The Erveheja figure is original, because it is functional within the structure figured transmittal, [11] social topos has maintained that it maintained social clichés, facts which were archived during the time. In the poetic structure of the poem, and especially in that of the heroin, the worldview differs from Muhammad Kyçyku's, view of life and society. For national internal reasons, he turned to literary evidence, which led to the creation of the strong dramatic character of Erveheja. As internal literary evidence, they are the product of the author's historical consciousness. Denying prosaic real life, he created the poetic life of the Albanian society. Erveheja deducted from God, up to his lap, by suffering. The embodied man, never the ugliness. The first approach to the divine beauty, for which is sacrificing so much. Figures of work, as Lessing says, make aesthetic effects by marking a deep impression to Albanians, as metaphysical essence of beauty. In his poem, the author found the opportunity to speak to his compatriot for problems that troubled the multiple meanings of simplicity, not by being a commercial speech. The overshadowed past, aimed to overcome the time, remained on time and trials narrative poem of the woman who believes in God succeeded. Personified social phenomena, being made to feel, by projecting themselves, their dreams and ideals. There was not a place in the center of the universe and individual desires, as the Sufis, features some of the best works in the Albanian tradition, which had replaced elements of mysticism. In the independent character, Erveheja has inherited many old features that serve as examples of cultural rigidity forces and political resistance (Kressing F., 2002). Thus, this narrative poem opens in a Bektashism way, as a religious and cultural heritage, the pure expression of the faith of Albanians, which will bring to Albanian literature Naim Frashëri. On this note, the philosophy of the Chinese Kong Fu Tzu writes: "Signs and symbols are the ones who dominate and lead the 
world, not words or laws." Erveheja marked the image of dignity, turning the symbol. It is therefore apparent that Erveheja led an infinitely beautiful moral life, as being named "man" intended something more than existence, and human dignity, that gives meaning to life. This work, therefore, conveyed this moral heritage by setting up the collective farm system in Albania after World War II. Communism was the cruelest enemy of human dignity. There was so much focus on the collective personality of each individual, that each life lost its uniqueness. People were cultivated in crowd psychology. Communism enjoyed without the crowds of citizens, encourages them to hate people who were obsessively concerned with dignity (exemplary honesty, was a legally banned religion, sometimes referred to as stupid, really depicted as pride). He appreciated a good man who did not distinguish himself in any of the others. In communism there was no worry about the perfection of the individual, and powerful talents had to suffer in silence, and in their drama. Dignity was an open threat to dictatorship; however, Erveheja works realized its social duty and put this in silence. The category of objective chance has given space to carry the offence makers, where the lady of the house simply has a queen value. In Arabic Ervehe means breeze, which had so much need Albanian resident. Create spaces of infinite possibility makers to hide crisis temperatures on the west side of the empire. With Erveheja, her fellow author offered little spiritual identity, little tenderness, a little kindness, and a little love, to people who had so much need. He offered his product as artistic sensitivity, as literature in their mother tongue, but not least as a culture, as moral, as indicated by strengthening utilitarian character, when crises threatened to multiply phony products, as stated in a quotation of Plato's Protagoras:

"Of course, I said, knowledge is the food of the soul and should beware, my friend, that sophist not deceive us when confess what sells, as extortionists who sell stuff for the body, because they praise indiscriminately all their goods without knowing who is really useful. .. The risk is much greater in the purchase of knowledge, rather than buy meat and drink ".

\section{References}

[1] Chami M. (1910). Erveheja, Selanik, p. IV.

[2] ibidem, p. V.

[3] ibidem, p. XII.

[4] Doja A. (2006) "A political history of Bektashism from Ottoman Anatolia to contemporary Turkey", Journal of Church and State, Vol. 48, No. 2. .. Oxford University Press, 1998.

[5] Doja A. (2008), Bektashizmi në Shqipëri: Histori politike e një lëvizjeje fetare, Tiranë.

[6] Frashëri K. (2006), Identiteti Kombëtar Shqiptar dhe Çështje të Tjera, Tiranë, 2006, p. 6.

[7] Hamiti S. (2010), Poetika shqipe, Tiranë, p. 147.

[8] Karamustafa T. A. (1994), God's unruly friends: Dervish groups in the Islamik later middle period 1200-1550, (Salt Lake City: University of Utah Press).

[9] Konica F. (1993), Vepra, Tiranë, 1993 (p. 227)

[10] ibidem, p, 226.

[11] Krasniqi B. (1984), Letërsia dhe vetëdija historike, Prishtinë, 1984.

[12] Kressing F. (2002), Preliminary account of research regarding the Albanian Bektashis. English, Book, Illustrated edition: Albania--a country in transition: aspects of changing identities in a South-East European country / [edited by] Frank Kressing, Karl Kaser, Baden-Baden: Nomos.

[13] Roller, Lynn E. (1999). In Search of God the Mother the Cult of Anatolian Cybele (Berkeley-Los Angeles: University of California Press). New Book on Magna Mater.

[14] Universiteti Shtetëror i Tiranës (USHT), Historia e Letërsisë Shqipe I, Tiranë, 1959, p. 284.

[15] Assoc. Prof. Faruk Kiliç A., The model of M. Akif Ersoy in the social crisis Resolution, $2^{\text {nd }}$ International Conference on Humanities "Crisis and Spirituality", 17-19 May 2013, Tirana.

[16] Dr. Balaban A., The importance of Using Language in Crisis Management, $2^{\text {nd }}$ International Conference on Humanities "Crisis and Spirituality”, 17-19 May 2013, Tirana.

[17] Prof. Dr. H. Taşdelen Musa, Sari Salltuk as a Spiritual Leader in the Balkans, $2^{\text {nd }}$ International Conference on Humanities "Crisis and Spirituality”, 17-19 May 2013, Tirana. 